This Journal is available in Telkom University online Journals

Jurnal Manajemen Indonesia

\title{
Industry 4.0: Strategy Direction Of An Airline Operations Performance
}

\author{
Dewi Nusraningrum ${ }^{1}$, Tri Mayang Mekar $^{2}$, Jajang Gunawijaya ${ }^{3}$ \\ ${ }^{1}$ Manajemen, UMB, Jakarta, Indonesia \\ ${ }^{2}$ Manajemen, UMB, Jakarta, Indonesia. \\ ${ }^{3}$ Manajemen, UI, Jakarta, Indonesia.
}

\begin{abstract}
Air transport is an industry 4.0 sector of priority that continues to evolve as the era becomes the backbone of a country's economy. The opening of the economic market in all regions of the world has increased the complexity of air transportation, including in Indonesia. In this decade as the development of technology and the 4.0 industry, the air plane remains the choice of people to explore the world and also the movement of people from one place to another is rapidly secured funds. The strategy to compete with the airline is to improve flight image in Indonesia by improving the performance of aviation operations. This research aims to analyse and evaluate the performance of aviation operations in Indonesia from the company's perspective. The survey method was conducted through the dissemination of questionnaires to respondents with purposive sampling techniques netted 200 aviation employees in Indonesia. The data collected is processed using the Structural Equation Model - Partial Least Square. The results showed; Strategy direction proved to affect process management, process management proved no effect on operation performance, strategy direction has no effect on Operation performance, strategy direction proved to affect human resources management, human resource management proved to be no impact on Operation performance, Process management proved unable to fully mediation the relationship between strategy direction with operating performance, HR management proved not to fully mediation the relationship between strategy direction to operating performance. So it can be said the strategy direction of the company directly affects the flight operation performance.
\end{abstract}

Keywords - Strategy direction; process management; human resource management; operation performance

\begin{abstract}
Abstrak
Transportasi udara merupakan sektor industri prioritas yang terus berkembang seiring perkembangan jaman yang menjadi tulang punggung ekonomi suatu negara. Terbukanya pasar ekonomi di seluruh wilayah dunia telah meningkatkan kompleksitas penyelenggaraan transportasi udara, termasuk di Indonesia. Dalam satu dekade ini seiring dengan berkembangnya teknologi dan industri 4.0, pesawat udara tetap menjadi pilihan masyarakat untuk menjelajahi dunia dan juga perpindahan manusia dari satu tempat ke tempat yang lain secara cepat dan aman. Strategi bersaing perusahaan penerbangan salah satunya adalah dengan meningkatkan citra penerbangan di Indonesia dengan meningkatkan kinerja operasi penerbangan. Penelitian ini bertujuan untuk menganalisis dan mengevaluasi kinerja operasi penerbangan di Indonesia dari perspektif perusahaan. Metode survei dilakukan melalui diseminasi kuesioner kepada responden dengan teknik purposive sampling terjaring 200 karyawan penerbangan di Indonesia. Data yang dikumpulkan diproses menggunakan Structural Equation Model - Partial Least Square. Hasil penelitian menunjukkan; Arah Strategi terbukti berpengaruh terhadap Manajemen Proses, Manajemen Proses terbukti tidak berpengaruh terhadap Kinerja Operasi, Arah Strategi tidak berpengaruh terhadap Kinerja Operasi, Arah Strategi terbukti berpengaruh terhadap Manajemen SDM, Manajemen Sumber Daya Manusia terbukti tidak berpengaruh terhadap Kinerja Operasi, Manajemen Proses terbukti tidak dapat memediasi hubungan Arah Strategi dengan Kinerja Operasi, Manajemen SDM terbukti tidak memediasi secara penuh hubungan antara Arah Strategi terhadap Kinerja Operasi. Sehingga dapat dikatakan arah strategi perusahaan secara langsung berpengaruh terhadap kinerja operasi penerbangan
\end{abstract}


Kata kunci-Arah Strategi; Manajemen Proses; Manajemen Sumber Daya Manusia; Kinerja Operasi

\section{INTRODUCTION}

The airline is one of the 4.0 industries that has become an integral part of modern human life because it is a fast, safe and even inexpensive means of transportation. This leads to more and more humans traveling using airplanes, previous research shows that the tendency of Indonesian people to air transport is to choose low-cost airline companies (Nusraningrum, 2014). This is contrary to the research results (Rahmani, 2003) that not all dimensions of innovation strategy include leadership orientation, product innovation type, process innovation type, internal innovation source, source of external innovation, and investment rate impacting operational performance measured by productivity level, product fault rate, warranty cost, quality cost, and timeliness of products to consumers.

According to Mc Dermott et. al. (1995), Doty et. al, (1993), Porter (1980), Miles and Snow (1978) stated that the strategy direction can lead to superior performance in a particular industry to fill a niche market. For example, Air Asia and Lion Air have been very successful following strategies focusing on providing low-cost flights where the airline business to gain profit (Nusraningrum, 2017). The airline with a full-service strategy such as Garuda Indonesia as a state-owned enterprise has ever achieved its success, before the low-cost flight deregulation was implemented in Indoensia in 2000. Nowadays airline companies with full service strategy should follow a slightly different strategy that puts greater emphasis on flexibility. Number of destinations and flights available.

The air transport market share in Indonesia is dominated by low-cost airline companies. Thus, the important factor that determines the success of the direction of the strategy in supporting the operation performance of the airline is how process management and human resource management can compete with other companies. Since operating decisions are made thousands of times per day by virtually every individual in the organization, an important prerequisite for effective decision making is that everyone has the authority in operation performance. Hayes \& Wheelwright (1984) mention that the operating strategy should provide a framework for individuals across a particular organization to make decisions about how best to provide transformation that results in products or services.

The strategy direction becomes an important factor to show the roadmap towards the company's strategic objectives. Alignment between the strategy direction and the goal of being a company's operating performance can be measured. Operation performance can be realized when supported by process management and human resource management as the mobilizer of the Organization (Boyer \& McDermott. 1999). This is because human resources work to push the organization in the direction it is intended. The main purpose of the study is to analyse the impact of the direction of the strategy on operating performance by looking at whether process management and human resource management can be variable between the strategy direction and the performance of the operation. Because of the importance of transportation services in every economy, measuring performance has become an integral part of industrial management and air transport is no exception (Tavassoli et al., 2014).

\section{LITERATURE REVIEW}

\section{Strategy Direction}

Siagian (2011) says that strategy is a series of fundamental decisions and actions made by top management and implemented by the whole range of an organization in order to achieve the organizational objectives. One of the objectives of the Organization is for the company to get as many customers as stated by Hamel and Prahalad (2000) strategy is an incremental action (always increasing) and continuously, and carried out based on the viewpoint of what future customers expect. The company's sustainability is determined by the long-term goal set, this is reinforced by David's (2011) and Morrisey (2002) strategies are a way of achieving long-term objectives for mission achievement. Business strategy can be geographic expansion, diversification, acquisition, product development, market penetration, employee rationalization, divestment, liquidation and joint venture. Supported with the opinions of Glueck and Jauch (2000) where the strategy is a unified, broad and integrated plan that connects the strategic excellence of the company with environmental challenges, designed to ensure that the company's main objectives can be achieved through proper implementation by the Organization. So that the direction of strategy becomes forward plan for the company. The strategy reflects the company's awareness 
of how, when and where it should compete against opponents and with what intent and purpose (Pearce and Robinson, 2008). While Halim (2007), Kaplan and Norton (2000) added a strategy is a way in which an institution or organization reaches a goal according to the opportunities and threats of external environments faced and the capabilities and resources and a set of hypotheses of a model in the causal relationship that is a relationship that can be expressed with the relationship between if and later.

\section{Process Management}

Stoner (2006) and Griffin (2004) say management is the process of making a planning, organizing, controlling and leading the various efforts of the members of the organization and also using all existing and owned resources to achieve the objectives that have been set effectively and efficiently. Effective means the objectives can be achieved according to what has been planned, and efficient means carry out the existing tasks correctly, organized, and also in accordance with the established schedule. So, management is a series of actions undertaken by the Organization and its members in an effort to achieve the objectives of the Organization. The process is a systematic activity (Wilson, 2013; Porter, 1985), because process innovations influence the organizational performance (Ettlie \& Reza, 1992). Process management represents the aspect of the system of management, while human resource management is the second aspect associated with human beings as the execution of such systems or processes. Some of the important elements of MSDM affecting operating performance include clear job descriptions of each job giving clarity to the item and the extent to which employees are expected to contribute. Competence is a major factor for the flight that is safe, secure, comfortable, timely and others in accordance with the expectations of the customer. As well as the training needed to maintain the adequacy of knowledge and skills although this has to go along with the high concern of its employees on the fulfillment of operating specifications and personnel as well as the performance of the operation itself. The assurance for performance operations is also possible when employees proactively deliver improvements to the management process and conduct meetings as an intense form of communication.

\section{Human Resource Management}

According to Hasibuan (2009) human resource management is the science and art of regulating the relationship and role of manpower in order to effectively and efficiently help the objectives of the company, employees and society. Human resource management activities include knowledge of the potential of employees and how a human resources manager can place and develop the whole human resource in the right position so that the company's performance can be optimal. The design of human resources placement is required as the guidelines and direction of the company's development so as to improve the performance of employees effectively and efficiently to achieve the objectives. It is reinforced by Hariandja (2002) that human resources are one of the very important factors in a company in addition to other factors such as capital, therefore human resources must be managed properly to improve the effectiveness and efficiency of the Organization. While Mathis and Jackson (2006), Mullins (2010) stated human resource management is a draft formal system in an organization to ensure the use of human talent effectively and efficiently to achieve organizational objectives, and a design strategy, implementation and maintenance to manage humans for optimal business performance including policy development and process to support the strategy.

\section{Operation Performance}

Performance is a multi-dimensional construct, which means that the influencing dimensions consist of a variety of factors, that can be seen from the quantity or quality of an action from a process involving a variety of activity components, and not only seen as a result that occurred at a certain point in a certain period of time (Amstrong \& Baron, 2005), and the work of a person based on the enhancement of such activities in accordance with the responsibilities and the results he hoped (Prawirosentono, 2001). Three kinds of company performance; Performance of operations, financial or accounting performance and marketing performance (Jahanshahi et. al., 2012; Prieto \& Revilla, 2006; Carton \& Hofer, 2006; Venkatraman \& Ramanujam, 1986). Performance assessment is intended to measure the effectiveness of the company's operations. The company's performance as measured by the financial statements approach is called financial performance using financial and accounting information such as profit before tax, return on investment and others (Rhoades et al., 2011). While non financial performance can be done using non financial approach as Kaplan and Atkinson (1998) mentioned such as; customer satisfaction, operations process (cost, quality, time), employee capabilities, information system capabilities, motivation, empowerment and alignment. Other performance measurements are based on the market performance that has a weakness can not control the incident and causes the uncertainty of feedback for the company (Healy,1995), and carry out its operational activities namely; "financial, marketing, gather and distribution of funds, technology, and Human Resource Management (Jumingan, 2006).” 
Operation of the airline in Indonesia is governed under Law No. 1 on Aviation year 2009, that means a flight is a unit of system consisting of the utilization of air areas, aircraft, airports, air transports, aviation navigation, safety and security, environment, and other supporting facilities and other public facilities. The operation performance of the airline is summarized in 3S1C, namely Security, Safety, Service and Compliance. Security because both the assets and the process of service require ' freedom of disturbance ' including the threat of terrorism which is lively several years. The airport as part of industry 4.0 and all activities are a national vital object in Indonesia. Secondly, safety is the need and expectation of all stakeholders in the context of Indonesian airline companies have gained criticism about the achievement of low safety performance with the occurrence of aircraft accident cases. Service is an indicator for the service sector that is demanded more intense for the airline compared with other transportation companies caused by consumers to spend greater costs than if using other modes of transportation. Ultimately, the guarantees on these three aspects are ensured by a series of government regulations and aviation associations that must be complied with.

Sampigethaya et al. (2011) Civil Aviation Regulations are strictly enforced for the airline to ensure that the safety of its passengers and aircraft. The performance of aviation operations can not be separated from economic growth in the community of users of air transportation services and also trends in global economic development. In line with the improved national economic growth, the role of the government as a regulator, is only responsible for issuing rules, conducting certification and supervision to ensure the implementation of air transportation that meets aviation safety standards. While Chang and Yeh (2002) said the aviation operations focus was on passenger comfort, service personnel, security and reliability, and ease of service. The performance of airport operators and airline companies in Indonesia is supervised and constructed by the Government to meet the stipulated standards (Nusraningrum 7 Waluyaningsih. 2013)

\section{HYPHOTHESES}

The hypotheses that have been tested in relation between variables or construction are:

1) Previous research showed that strategic plan or direction of the company's strategy positively influence the process management or implementation of strategic plan (Nusraningrum et al., 2021; Natasha \& Devie, 2013).

H1: Strategy direction has a positive influence on process management.

2) The results of previous research showed that the process management in which there is innovation process positively affect the operation performance (Nusraningrum et al., 2021; Ettlie \& Reza, 1992; Rita, 2010).

H2: Process Management has a positive impact on operation performance.

3) Previous studies have shown that strategy direction has a positive influence on operation performance (Nusraningrum et al., 2021; Natasha \& Devie, 2013).

H3: Strategy direction has a positive influence on operation performance.

4) Previous research showed that the strategy direction of positive effect on human resource management (ÇALIŞKAN, 2010).

H4: Strategy direction has a positive influence on human resource management.

5) The results of previous research showed that human resource management will enable the company to design programs that will produce better operational outcomes to achieve higher organizational performance, so that human resource management has a positive effect on operation performance (ÇALIŞKAN, 2010).

H5: HR Management has a positive impact on operation performance.

6) Previous research showed that process management when measured using productivity improvements can be used as an intervening variable for operation performance (Wurjaningrum, 2012). While other studies have found that the process management cannot be an intervening variable (Massudi, 2015).

H6: Process management as a moderator between strategy direction and operation performance.

7) The results of previous research showed that human resource management when measured using compensation (Aji, et al., 2017) and when measured using job satisfaction (Iis \& Mukhlis, 2014) can be used as an intervening variable. 
H7: Human resource management as a moderator between strategy direction and operation performance.

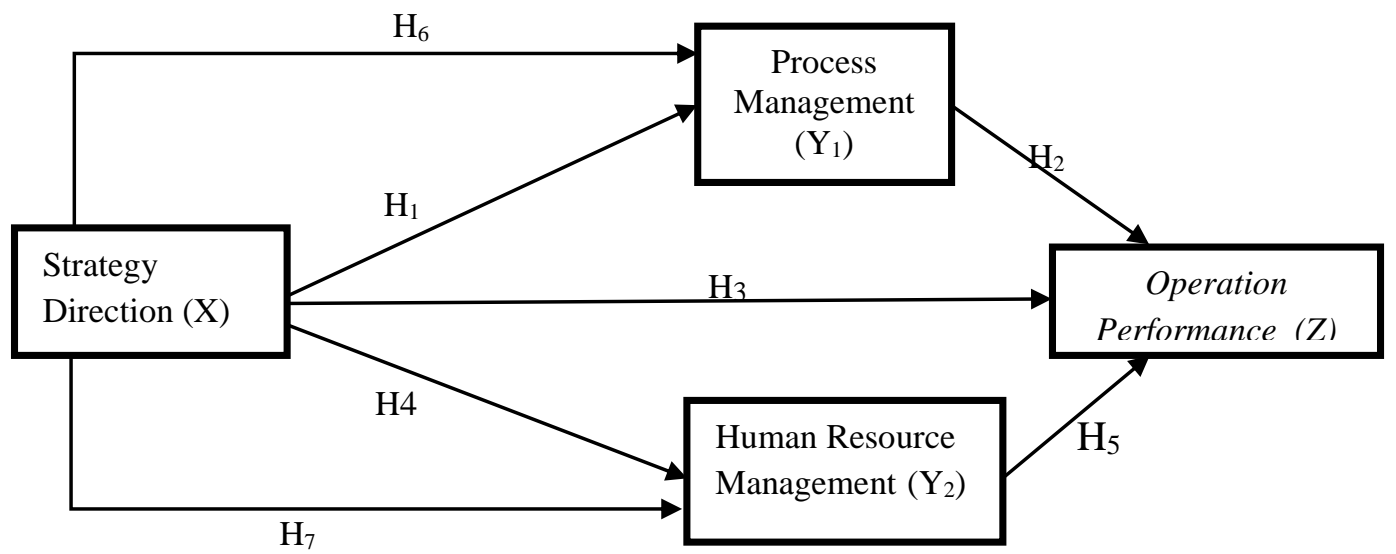

Fig 1. Research Model

\section{METHODOLOGY}

The research process begins with identifying issues in the research, formulating problems, and the basis of basic theories to reinforce the underlying theory of each variable. Furthermore, the preparation method in data collection, the preparation of the instrument until the testing technique conducted, the subject used by the researcher is an active employee of the commercial airline scheduled in Indonesia. The study carried out January 2019 to November 2019.

Table 1. Operationalization Variables

\begin{tabular}{lllc}
\hline No. & \multicolumn{1}{c}{ Variable } & \multicolumn{1}{c}{ Indicator } & Scale \\
\hline $1 . \quad \begin{array}{l}\text { Strategy Direction } \\
\text { (Exogenous) }\end{array}$ & 1. & $\begin{array}{l}\text { The company uses corporate strategy to create growth for the } \\
\text { company thoroughly. }\end{array}$ & Ordinal \\
& 2. & $\begin{array}{l}\text { The company uses business strategy through its cost excellence } \\
\text { strategy, differentiation strategy and focus strategy. }\end{array}$ \\
3. & $\begin{array}{l}\text { The company uses its functional (Value-based-strategy) strategy } \\
\text { as; Operations, marketing, finance, and human resources for the } \\
\text { fulfillment of customer needs }\end{array}$
\end{tabular}

2. Process Management (Endogenous)

3. Human Resource Management (Endogenous)
1. The company has organizational structure.

2. The organizational structure establishes a delegation of clear authority and responsibilities.

3. The organizational structure runs well and helps the company's operating performance.

4. Each department understands its authority and responsibilities well.

5. Detailed tasks in accordance with the authority, responsibilities and positions in the company.

6. The company has accountability centres.

1. The company makes human resource planning HR planning is Ordinal made by coordinating with related departments/sections.

2. Employee selection is conducted at all departments level according to required competencies.

3. Introduction and orientation are implemented for all new employees. 
4. Training and human resource development are organized for all employees.

5. Performance assessment applies to all employees.

6. Awards and compensation are provided to all employees.

7. Career planning and development is applied to all employees.

8. Replenishment of HR needs takes precedence over internal.

4. Operation Performance 1. Punctuality / On-Time Performance per operation (OTP)

(Endogenous) 2. Load Factor per Flight

3. Daily aircraft utilization (hour).

4. Revenue passenger per kilometers

5. Available seat kilometers

6. Revenue per workload unit

7. The company conducts periodic customer satisfaction surveys

Source: processed by the author, 2019

The population in this research is an unknown employee of the Indonesian airline company. While the sample (Sugiyono, 2014) which is part of the number and characteristics owned by the population using the purposive sampling technique is a sampling technique with a sampling technique with certain considerations in accordance with the characteristics prescribed by the researcher amounted to 125 people. According to Hair, et.al. in (Lupiyoadi et. al, 2014) suggested that the sample size to be used when using SEM techniques, then the number of samples between 100-200.

Primary Data is obtained from respondents of various airline employees in Inodnesia. The Structure Equation Model is used to thoroughly explain the relationship between variables in the study. The relationship was constructed between one or more independent variables (Santoso, 2011). SEM is used as a more potent alternative to the use of multiple regression, pathway analysis, factor analysis, time series analysis and covariant analysis (Byrne, 2010). Yamin (2009) suggested that in the SEM research can do three activities at once, namely Validity examination and instrument reusability (equivalent to the analysis of the confirmatory factor), testing the relationship model between the latent variables (equivalent to the analysis path) and obtaining a beneficial model for prediction (equivalent to structural model or regression analysis).

And the analysis tool used is Partial Least Square (PLS), PLS is the method of analysis of Componant or Variance Based Structural Equation Modeling in which the data processing is Partial Least Square program (Smaart-PLS) version 3.0. PLS (Partial Least Square) is an alternative model of covariance based SEM. PLS intended for Causal-Predictive analysis in high complexity situation and low theory support (Ghozali, 2014). The purpose of PLS is to find the optimal predictive linear relationship present in the data. Although PLS can also use confirm theory, but can also be used to explain the presence or absence of relationship between latent variables. As stated by Wold in Ghozali (2014) Partial Least Square (PLS) is a powerful method of analysis is therefore not based on many assumptions, so the data should not be distributed normal multivariative and the samples should not be large.

\section{RESULT}

1. Evaluate the Measurement Model (Outer Model)

a. Convergent Validity

Testing of the Convergent Validity of each construction indicator. According to Ghozali (2014), an indicator is said to have a good valid if the value is greater than 0.70 while the loading factor 0.50 to 0.60 can be considered sufficient. Based on these criteria when there is a loading factor below 0.50 It will be dropped from the model.

Table 2. Convergent Validity Test

\begin{tabular}{cccc}
\hline Variable & Indicator & Outer Loadings & Note \\
\hline Strategy Direction & AS1 & 0.882 & Valid \\
& AS2 & 0.928 & Valid \\
Process Management & AS3 & 0.907 & Valid \\
& MP1 & 0.561 & Valid \\
& MP2 & 0.686 & Valid \\
& MP3 & 0.849 & Valid
\end{tabular}




\begin{tabular}{|c|c|c|c|}
\hline \multirow{5}{*}{$\begin{array}{c}\text { Human Resource } \\
\text { Management }\end{array}$} & MP4 & 0.819 & Valid \\
\hline & MP5 & 0.829 & Valid \\
\hline & MP6 & 0.901 & Valid \\
\hline & MSDM1 & 0.795 & Valid \\
\hline & MSDM2 & 0.844 & Valid \\
\hline \multirow{14}{*}{ Operation Performance } & MSDM3 & 0.851 & Valid \\
\hline & MSDM4 & 0.738 & Valid \\
\hline & MSDM5 & 0.805 & Valid \\
\hline & MSDM6 & 0.704 & Valid \\
\hline & MSDM7 & 0.678 & Valid \\
\hline & MSDM8 & 0.763 & Valid \\
\hline & MSDM9 & 0.564 & Valid \\
\hline & KO1 & 0.470 & Not Valid \\
\hline & $\mathrm{KO} 2$ & 0.719 & Valid \\
\hline & $\mathrm{KO} 3$ & 0.742 & Valid \\
\hline & KO4 & 0.773 & Valid \\
\hline & KO5 & 0.828 & Valid \\
\hline & KO6 & 0.586 & Valid \\
\hline & KO7 & 0.541 & Valid \\
\hline
\end{tabular}

Based on the data on table 1 It is known that each of the multiple research variables indicator has an outer loading value of $>0.7$. However, there are still several indicators that have an outer loading value of less than 0.7. According to Chin as quoted by Ghozali (2014), the value of outer loading between 0.5 to 0.6 is already considered sufficient to qualify convergent validity. The outer loadings value below 0.5 is declared invalid. Therefore, it is necessary to make modifications by dropping or removing the indicators that have a value below 0.5 (KO1) in order for the indicator to be valid or further analysis can be performed.

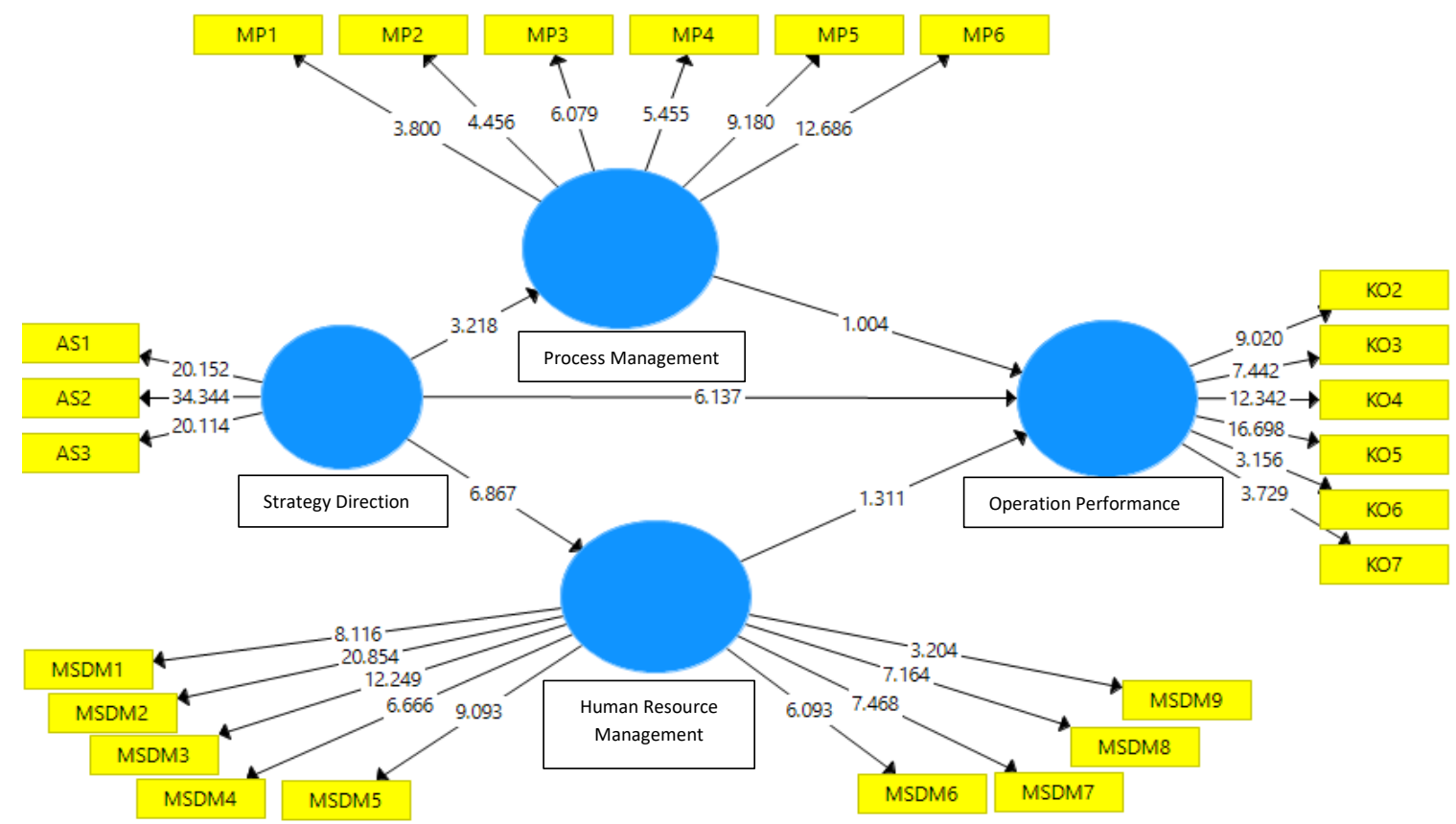

Fig 2. Modifications of Convergent Validity

The result of testing modifications convergent validity in Figure 1 above can be seen that all indicators have influenced convergent validity because it has a loding factor value above 0.50 . 


\section{b. Discriminant Validity}

Testing linear validity, reflective indicators can be seen in cross loading table between indicators with its construction. An indicator is considered valid if it has the highest loading factor to the intended construct versus the loading factor of the other conductor. Thus, the latent construct predicts the indicators on their blocks better compared to other block indicators.

Table 3. Discriminant Validity (Cross Loadings)

\begin{tabular}{ccccc}
\hline Indicator & Strategy Direction & Process Management & HRM & $\begin{array}{c}\text { Operation } \\
\text { Performance }\end{array}$ \\
\hline AS1 & & & 0.730 \\
$A S 2$ & 0.883 & 0.276 & 0.585 & 0.569 \\
$A S 3$ & 0.929 & 0.384 & 0.626 & 0.506 \\
$M P 1$ & 0.906 & 0.480 & 0.339 & 0.231 \\
$M P 2$ & 0.238 & 0.553 & 0.519 & 0.025 \\
$M P 3$ & 0.233 & 0.680 & 0.608 & 0.164 \\
$M P 4$ & 0.288 & 0.851 & 0.620 & 0.211 \\
$M P 5$ & 0.320 & 0.823 & 0.565 & 0.259 \\
$M P 6$ & 0.388 & 0.831 & 0.597 & 0.355 \\
$M S D M 1$ & 0.423 & 0.903 & 0.796 & 0.289 \\
$M S D M 2$ & 0.563 & 0.498 & 0.843 & 0.415 \\
$M S D M 3$ & 0.712 & 0.662 & 0.853 & 0.253 \\
$M S D M 4$ & 0.539 & 0.537 & 0.735 & 0.137 \\
$M S D M 5$ & 0.310 & 0.646 & 0.804 & 0.313 \\
$M S D M 6$ & 0.370 & 0.540 & 0.763 & 0.141 \\
$M S D M 7$ & 0.388 & 0.496 & 0.677 & 0.124 \\
$M S D M 8$ & 0.385 & 0.422 & 0.765 & -0.036 \\
$M S D M 9$ & 0.443 & 0.363 & 0.595 & 0.731 \\
KO2 & 0.190 & 0.450 & 0.261 & 0.743 \\
KO3 & 0.600 & 0.264 & 0.142 & 0.776 \\
KO4 & 0.453 & 0.155 & 0.120 & 0.853 \\
KO5 & 0.434 & 0.187 & 0.126 & 0.593 \\
KO6 & 0.483 & 0.127 & 0.310 & 0.534 \\
\hline KO7 & 0.363 & 0.192 & 0.494 & \\
\hline
\end{tabular}

Data from table 3, It can be seen that the correlation of the construction Strategy Direction (X) with the input is AS1 up to AS3 is higher than the correlation of indicators with other construct (process management, HR management and operating performance), then the correlation of the Process management construction (Y1) with the indicator is MP1 up to MP6 higher than the indicator correlation with other contractors (strategy direction, HR management and operating performance). Then the correlation between HR management (Y2) and its indicator is MSDM1 up to MSDM9 higher than the correlation indicators with other contractors (strategy direction, process management and operation performance) subsequent correlation between the performance of operation $(\mathrm{Z})$ and its indicator is $\mathrm{KO} 2$ up to $\mathrm{KO} 7$ higher than the other contruction (strategy direction, process management and human resource management).

In addition to viewing linear validity with the cross loadings method there are other methods of using the average variance extracted (AVE), in the AVE method there is a good model requirement if AVE each construction of a greater value of 0.50 .

Table 4. AVE Result

\begin{tabular}{ll}
\hline \multicolumn{1}{c}{ Variable } & Valid $>\mathbf{0 . 5 0}$ \\
\hline Strategy Direction & 0.821 \\
Process Management & 0.621 \\
Human Resource Management & 0.569 \\
Operation Performance & 0.505 \\
\hline
\end{tabular}

c. Composite Reliability and Cornbach's Alpha 
Composite realibility testing aims to test the reliability of instruments in a research model. If all latent variable values have a composite reliability value or Cronbach's alpha $>0.70$. This means that the construct has good reliability or the questionnaire used as a tool in this study has been reliably or consistently (Ghozali, 2014).

Table 5. Composite Reliability \& Cronbach's Alpha Result

\begin{tabular}{lcccc}
\hline \multicolumn{1}{c}{ Variable } & Composite Reliability & Note & Cronbach's Alpha & Note \\
\hline Strategy Direction & 0.932 & Reliable & 0.891 & Reliable \\
Process Management & 0.903 & Reliable & 0.870 & Reliable \\
Human Resource Management & 0.921 & Reliable & 0.906 & Reliable \\
Operation Performance & 0.857 & Reliable & 0.798 & Reliable \\
\hline
\end{tabular}

2. Structural/hypothesis Test (Inner model)

a. R-Square value as a goodness-fit model test

Table 6. $\mathbf{R}^{2}$ Value

\begin{tabular}{cc}
\hline Endogenous variables & $\mathrm{R}^{2}$ \\
\hline Process Management & 0.177 \\
HR Management & 0.394 \\
Operation Performance & 0.469 \\
\hline
\end{tabular}

According to table 6 above, it can be explained that the R-square or Koefesien value of process management is 0.177 this means that $17.7 \%$ of variation value or process management changes are influenced by strategy direction, while the remaining $82.3 \%$ is influenced by other variables. Meanwhile, the value of R-square or the coagulating of human resources management is 0.394 this means that $39.4 \%$ of variation values or changes in human resource management are influenced by strategy direction, while the remaining $60.6 \%$ are influenced by other variables. And the value of R-Square or Koefesien detemination operation performance is 0469 this means that $46.9 \%$ of variation values or changes in operation performance are influenced by strategy direction, process management and human resource management, while the remaining $53.1 \%$ is influenced by other variables.

b. Goodness of Fit Model

Testing the Goodness of fit model structure uses the value predictive relevance $\left(\mathrm{Q}^{2}\right)$. The $\mathrm{Q}$-square value greater than 0 (zero) indicates that the model has a value predictive relevance. Calculation results:

$$
\begin{aligned}
& \mathrm{Q}^{2}=1-(1-\mathrm{R} 1)(1-\mathrm{R} 2)(1-\mathrm{R} 3) \\
& \mathrm{Q}^{2}=1-(1-0.1772)(1-0.3942)(1-0.4692) \\
& \mathrm{Q}^{2}=0.362
\end{aligned}
$$

Calculation result of predictive relevance value $0362>0$. This means that $36.2 \%$ of the variation in the operation performance, process management and human resources management (variable dependent) variables are explained by the variables used. Thus the model is said to be worthy of having the relevant predictive value.

c. Hypothesis testing results (estimation of path coefficient)

The estimate value for the relationship path in the structural model must be significant. This significant value can be obtained by the boostrapping procedure. See the significance on the hypothesis by looking at the parameter coefficient value and the value of T-Statistic significance on the Alogarithm boostropping report. To find out significant or insignificant views of the T-table at Alpha $0.05(5 \%)=1.96$. Then T-table compared to T-count (t-Statistic).

Table 7. Hypothesis Testing

\begin{tabular}{cccccc}
\hline $\begin{array}{c}\text { Original } \\
\text { Smple (O) }\end{array}$ & $\begin{array}{c}\text { Sample } \\
\text { Mean (M) }\end{array}$ & $\begin{array}{c}\text { Standard } \\
\text { Deviation } \\
(\text { STDEV) }\end{array}$ & $\begin{array}{c}\mathrm{t}- \\
\text { stats }\end{array}$ & $\begin{array}{c}\text { P- } \\
\text { values }\end{array}$ & Note \\
& & & \\
\hline
\end{tabular}




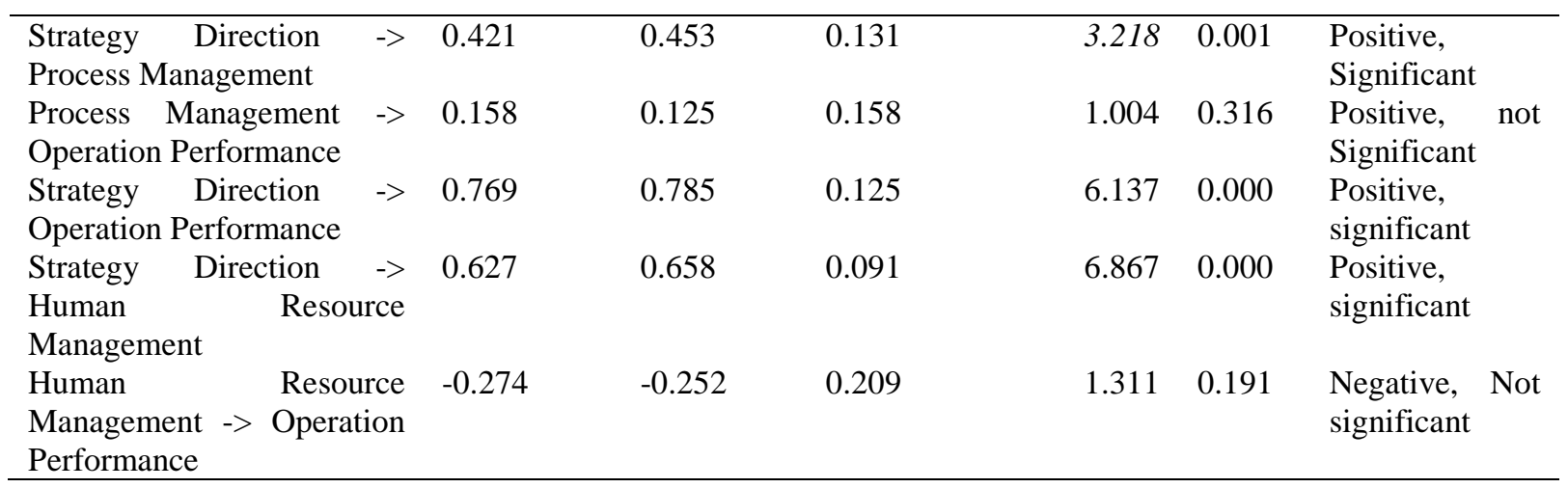

\section{Analysis of Path Coefficient}

From the processed data, it can be demonstrated that the strategy direction $(\mathrm{X})$ has an original sample value of 0421 which shows the relationship between strategy direction (X) with process management (Y1) is positive and for T-Statistic of 3,218. By using the significance $>\mathrm{T}$ table 1.96 and P-Value $0.001<0.05$. Thus, the first hypothesis (H1) that states the strategy direction $(\mathrm{X})$ affects the process management (Y1) is proved.

For process Management (Y1) has a positive impact on the operating performance (Z) that is seen from the original value of the sample of 0158 . While the influence of process management (Y1) on Operation Performance $(Z)$ is insignificant, it is seen from the T-Statistic of 1,004 which means it is not fulfilled meet the provisions (T-Statistic < t-table 1.96) as well as the value P-Value $0316<0.05$. Thus the second hypothesis (H2) states process Management (Y1) affects the performance of operations (Z) is rejected.

Furthermore, strategy direction $(\mathrm{X})$ has a positive influence with performance operation $(\mathrm{Z})$ seen from the original value of the sample of 0769 . The influence of the strategy direction towards operation performance is significant, it is seen from the T-Statistic of 6,137 which means it meets the provisions (T-Statistic > T-table $1.96)$ as well as the value of P-Value $0.000<0.05$. Thus, the third hypothesis $(\mathrm{H} 3)$ states the Strategy Direction $(\mathrm{X})$ affects the operation performance $\mathrm{s}(\mathrm{Z})$ is proved.

Results from processed data indicate that the strategy direction $(\mathrm{x})$ has an original sample value of 0627 which means that the strategy direction variable $(\mathrm{x})$ has a positive effect on human resources (Y2) with a TStatistic value of 6,867 which means that it meets the provisions (T-Statistic > T-table 1.96) as well as the value $\mathrm{P}$-value $0.000<0.5$. Thus, the fourth hypothesis $(\mathrm{H} 4)$ states the influential strategy direction of $\mathrm{HR}$ Management (Y2) is received.

Human Resource Management (Y2) has a negative impact with the operation performance (Z) which is visible from the original value of the sample of -0274. While the influence of human resource management (Y2) on performance operations (Z) is insignificant, it is seen from the T-Statistic of 1.311 which means it does not meet the provisions (T-Statistic $<$ t-table 1.96) and the value P-Value $0.191<0.05$. It can then be stated that the fifth hypothesis (H5) states that human resource management affects the performance of the operation is rejected.

Variables Mediators on Path Analisis

Variable mediators are also called intervening variables or process variables. Ghozali (2013) says the intervening variable is a variable between or mediating, which functions mediate the relationship between the independent variables and the dependent variables. Mediation occurs if the Predictor or independent variable affects the dependent variable indirectly through at least one intervening variable or mediator. If it consists of only one mediator then it is called simple mediation and if the mediational process involves more than one mediator then it is called with multiple mediation.

Process Management Mediation (Y1) and HR Management (Y2) test results with the causal step method demonstrate that the influence of strategy direction (X) on process Management (Y1) is significantly seen from the T-Statistic value $3.218>$ t-table 1.96, and P-Value $0.001<0.05$. The relationship between Process Management (Y1) with Operation performance (Z) not significant on t-count $1.004<1.96$ and P-Value $0.316<$ 0.05 . The influence between strategy direction $(X)$ toward operation performance $(Z)$ is significant with t-count $6.867>1.96$ and P-Value 0.000. Based on these three relationships it can be concluded that process management (Y1) is unable to mediate the relationship Strategy Direction (X) with Operation Performance (Z). So, that the sixth hypothesis (H6) is rejected. 
Subsequent testing results show that the influence of Strategy Direction (X) on HR Management (Y2) is a significant view from T-count $6.867>1.96$ on P-Value $0.000<0.5$. HR Management Relationship (Y2) on Operation Performance $(\mathrm{Z})$ is not significant, it is seen from T-count $1.311<1.96$ on $\mathrm{P}$-Value $0,191<0.05$. While the influence between strategy direction $(X)$ to operation performance $(Z)$ is a significant with $\mathrm{T}$-count $6.137>$ T-table 1.96 on P-Value $0,000<0.05$. Based on all three relationships, it can be concluded that HR management (Y2) does not fully process (full mediation) the relationship between Strategy Direction (X) to Operation Performance $(\mathrm{Z})$. So, that the seventh hypothesis $(\mathrm{H} 7)$ is rejected.

\section{DISCUSSION}

1) The first hypothesis proved that strategic direction has positive and significant effect on operating performance, the findings are supported by previous research results indicating that the strategic plan or direction of the company's strategy positively affects the process management or implementation of the Strategic plan (Natasha \& Devie. 2013). This gives an overview that the operation performance requires a visible strategy direction of the strategy plan made by the company (Nusraningrum et al., 2021)

2) The second hypothesis proved that process management positively and insignificant effect on operating performance. These findings provide an overview when process management does not include process innovations at the time of measure, so process management has an insignificant influence on the performance of operations such as previous research results indicating that the process management in which there is a process innovation positively influence the operation performance (Nusraningrum et al., 2021; Ettlie \& Reza, 1992; Rita, 2010).

3) The third hypothesis proved that the strategy direction is influential positively and significantly towards the performance of the operation, the results of this study are supported by previous findings (Natasha \& Devie. 2013). It can be said that the operation performance is a company goal that must be achieved, where in achieving the company objectives the strategy direction of the company should be clear towards the expected goal (Nusraningrum et al., 2021)

4) The fourth hypothesis proved that the strategy direction has a positive and significant impact on human resource management, the findings are supported by previous research shows that the strategy direction positively affects the management of human resources that are Stratejic (ÇALIŞKAN, 2010). That in the company of human resource management must be managed in a stratejic way.

5) The fifth hypothesis proved that HR management has a negative and insignificant effect on operating performance, this is the case with the possibility that human resource management in the Indonesian airlines has not designed a program that can support the performance of the operation for the better. These findings contradict the results of previous research showed that human resource management will enable the company to design programs that will produce better operational outcomes to achieve higher organizational performance, so that human resource management positively influence the operation performance (ÇALIŞKAN, 2010).

6) The sixth hypothesis was rejected, because although the strategy direction was influential against process management but the process management influenced insignificant impact on operation performance. The results of this research in accordance with the previous findings, namely process management when measured using productivity improvements can be used as a moderator variable (Wurjaningrum, 2012). Meanwhile, in this research process management is not measured with productivity improvements, so the process management can not be a moderator variable (Massudi, 2015).

7) The seventh hypothesis was rejected, because although the strategy direction proved to affect the operation performance but human resource management had no effect on the operation performance. This research provides an overview of the possibility to parse the human resource management variables into variables with a more limited scope in accordance with the results of previous research showed that human resource management when measured using compensation (Aji, et al., 2017) and when measured using job satisfaction (Iis \& Mukhlis, 2014) can be used as a intervening variable.

\section{CONCLUSIONS}

Findings on this research are; Strategy direction proved to affect process management, where process management cannot process properly if the airline as an industry 4.0 does not have a clear strategy direction. Process management proved to affect operation performance but not significantly, so that the influence of 
process management became a significant process innovation needed therein. Strategy direction proved to affect operation performance, this finding indicates that in order to achieve optimal operation performance as a company objective is needed direction of appropriate company strategy so that the company's objectives can be achieved. Strategy direction proved to affect human resource management, it proves that in managing human resources needed clear strategy direction. Human resource management proved to be negatively and insignificant to the operation performance, this finding gives an overview when the human resource management does not have a clear program it will negatively affect the operating performance of the airline as an indutry 4.0. Based on the findings, the process management proved not to be able to process the relationship of strategy direction with operation performance, so also the human resource management proved to be unable to fully mediated of the relationship between strategy direction and operation preformance.

\section{Limitations}

This research has limitations to access the top leadership of airlines in Indonesia, and those who are willing to fill out questionnaires are employees of scheduled commercial flights in Indonesia ranging from level two management to line employees. So this research still has the opportunity to do further research, considering the occurrence of the Covid-19 pandemic that is still ongoing to this day, there is a possibility of differences in perception of flight operations not only in Indonesia but around the world.

\section{REFERENCES}

Aji, Sunu Waskito. Suddin, Alwi. Suseno, Y. Djoko. 2017. Analisis Pengaruh Kepemimpinan Dan Kompetensi Terhadap Kinerja Melalui Kompensasi Sebagai Variabel Intervening. Jurnal Manajemen Sumber Daya Manusia. Vol. 11 No. 2. Pp. 306 - 316.

Armstrong, Michael. Angela Baron. 2005. Performance Management. London: Institute of Personnel and Development.

Bangun, Wilson. 2013.Manajemen Sumber Daya Manusia. Jakarta. Erlangga.

Boyer, Kenneth K. Christopher McDermott. 1999. Strategic consensus in operations strategy, Journal of Operations Management. Vol. 17. Pp. 289-305.

Butler, Gail. Martin R. Keller. 2000, Handbook of Airline Operations, New York. McGraw Hill.

ÇALIŞKAN, Esra NEMLİ, 2010. The Impact Of Strategic Human Resource Management On Organizational Performance. Journal of Naval Science and Engineering. Vol. 6. No.2. pp. 100-116.

Carton R. B., Hofer C.W. (2006). Measuring Organizational Performance: Metrics for Entrepreneurship and Strategic Management Research. Edward Legard Publishing Limited.

David, Fred R. 2011. Strategic Management: Concept 13rd edition. Pearson Prentice Hall International. New Jersey. England.

Fahmi. Irham. 2012. Analisis laporan Keuangan. Cetakan ke-2. Bandung. Alfabeta.

Glueck dan Jauch. 2000. Manajemen Strategis dan Kebijakan Perusahaan. Edisi Ketiga. Terjemahan Murad dan Henry. Erlangga. Jakarta.

Ghozali, Imam. 2014. Structural Equation Modeling, Metode Alternatif dengan Partial Least Square (PLS). Edisi 4. Semarang. Universitas Diponegoro.

Grant, Robert M. 1999. Analisis Strategi Kontemporer, Konsep, Teknik, Aplikasi. Edisi Kedua. Jakarta: Erlangga.

Griffin, Ricky W. 2004. Manajemen; edisi ketujuh jilid 1. Jakarta: Erlangga.

Halim, Abdul. 2007. Manajemen Keuangan Bisnis. Bogor: Ghalia Indonesia.

Hamel, Gary dan CK. Prahalad. 2000. Kompetisi Masa Depan; Strategi-Strategi Terobosan Untuk Merebut Kendali Atas Industri Anda Dan Menciptakan Pasar Masa Depan. Jakarta. Binarupa.

Hariandja, Marihot Tua Efendi. 2002. Manajemen Sumber Daya Manusia. Grasindo, Jakarta.

Hasibuan, S.P. Malayu, 2009. Manajemen Sumber Daya Manusia. Cetakan Ketujuh. PT. Bumi Aksara, Jakarta. 
Iis, Em Yusuf. Yunus, Mukhlis. 2014. Job Satisfaction as an Intervening Variable of Self Efficacy and Employee Performance International. Journal of Academic Research in Business and Social Sciences. Vol. 6, No. 7. Pp. 284-298.

Ikatan Akuntan Indonesia. 2007. Standar Akuntansi Keuangan. Jakarta:Salemba Empat.

Jahanshahi, A.A.., Rezaei, M., Nawaser, K., Ranjbar, V., Pitamber, B. K. (2012). Analyzing The Effect of Electronic Commerce on Natasha: Analisa Pengaruh Strategic Planning Terhadap Keunggulan Bersaing dan Kinerja Perusahaan 195 Organizational Performance: Evidence From Small and Medium Enterprise. African Journal of Business Management, Vol.6, No.15, 6486- 6496.

John A, Pearce II. Richard B.Robinson, Jr., 2008. Manajemen Strategis Formulasi, Implementasi dan Pengendalian. Jakarta. Salemba Empat.

Jumingan. 2006. Analisa Laporan Keuangan. Jakarta. Bumi Aksara.

K. Sampigethaya, W. Beck, K. Lane, S. Lintelman and R. Poovendran. 2011. Future E-Enabled Aircraft Communications and Security: The Next 20 Years and Beyond, Vol. 99, No. 11, Elsevier Science in ProQuest Ebook Central, viewed 20 March 2017.

Kaplan, Robert S. David P. Norton. 2000. Balanced Scorecard. Menerapkan strategi menjadi aksi. Erlangga. Jakarta.

Kotler, Philip dan Gary Armstrong. 2016. Prinsip-prinsip Pemasaran. Jilid 1' Edisi Kedelapan, Jakarta. Erlangga.

Kotler, Philip. 2016. Manajemen Pemasaran. Jilid 1. Edisi Milenium, Jakarta. Prehallindo.

Kotler. Philip dan Gary Armstrong. 2016, Prinsip-prinsip Pemasaran. Jilid 2. Edisi Kedelapan. Jakarta. Erlangga.

Law of the Republic of Indonesia Number 1 Year 2009 on Aviation. (www.vertic.org/media/.../Indonesia/ID_Aviation\%20Act). Accessed 20 March 2017.

Massudi, Marannu. 2015. Pengaruh Entrepreneurial Leadership Dan Good Governance Terhadap Operational Performance Melalui Business Process Management Sebagai Variabel Intervening Pada Usaha Kecil Menengah Sentra Batik Tulis Surabaya. Jurnal Ekonomi dan Bisnis Airlangga. Vol 25, No 3. Pp.210-221.

Mathis Robert L. Jackson John H. 2002. Human Resource Management. Alih Bahasa. Salemba Empat. Jakarta.

Morrisey. 2002. Perencanaan Jangka Panjang, Terjemahan: Ramelan. Jakarta: Prehalindo.

Mullins. Laurie J. 2010. Management \& Organisational Behaviour. Ninth Edition. Pearson.

Mulyadi. 2007.Sistem Akuntansi. Jakarta. Selemba Empat.

Natasha, Priscilla. Devie. 2013. Analisa Pengaruh Strategic Planning Terhadap Keunggulan Bersaing Dan Kinerja Perusahaan. Business Accounting Review, Vol. 1, No.2. Pp. 185-195.

Nusraningrum, Dewi. Waluyaningsih, Nur. 2013. Performance Analysis: The Case of Directorate General of Civil Aviation Using Balanced Scorecard. World Journal of Social Sciences, Vol. 3, No. 3, pp. 98-119.

Nusraningrum, Dewi. 2017. Performance of Aircraft Technicians: The Case of Indonesia. World Review of Business Research Vol. 7. No. 2. September 2017 Issue. Pp. $105-118$.

Nusraningrum, Dewi. Santoso, S. Gunawijaya, J. Gading, DK. 2021. Green Operations Management with Green Business and Green Marketing Perspective. Psychology And Education. 58(2). Pp. 4526-4535.

Nusraningrum, Dewi. Isa, Salmi Mohd. Mulia, Dipa. 2021. Industrial 4.0 of Service and Manufacturing in JavaIndonesia: Level of Implementation (Industri 4.0 pada Sektor Jasa dan Manufaktur di Jawa-Indonesia: Tingkat Implementasi). Operations Excellence: Journal of Applied Industrial Engineering. 13(1). Pp. 36-46.

Prawirosentono, Suyadi. 2001. Kebijakan Kinerja Karyawan: Kiat Membangun Organisasi Kompetitif Menjelang Perdagangan Bebas Dunia. Yogyakarta. BPFE.

Prieto, I. M., \& Revila E. (2006). Learning Capability and Business Performance: A Non-Financial and Financial Assessment. Journal of The Learning Organization, 13(2), 166-185.

Rahmani, Eny. 2003. Pengaruh strategi inovasi terhadap kinerja operasional perusahaan manufaktur di Indonesia. Yogyakart., Universitas Gadjah Mada. 
Rhoades, D.L., Rechner, P.L., Sundaramurthy, C. 2000. Board composition and financial performance: A meta-analysis of the influence of outside directors. Journal of Managerial Issues. Vol. XII. Pp. 76-91.

Rita. 2010. Pengaruh Strategi Inovasi Terhadap Kinerja Operasional Perusahaan Manufaktur. Binus Business Review. Vol.1 No.2. pp. 474-487.

Rivai, Vethzal. Basri. 2005. Peformance Appraisal: Sistem yang tepat untuk Menilai Kinerja Karyawan dan Meningkatkan Daya Saing Perusahaan. Jakarta. PT. Raja Grafindo Persada.

Sawir. Agnes. 2005. Analisis Kinerja Keuangan dan Perencanaan Keuangan. Jakarta. PT. Gramedia Pustaka Utama.

Siagian, Sondang P. 2011. Manajemen Sumber Daya Manusia. Jakarta. Bumi Aksara.

Stoner, James AF. 2006. Management. Englewoods Cliffs, New York. Prentice Hall. Inc.

Tavassoli, Mohammad. Gholam Reza Faramarzi. Reza Farzipoor Saen. 2014. Efficiency and effectiveness in airline performance using a SBM-NDEA model in the presence of shared input. Journal of Air Transport Management. Vol. 34. pp. 146-153.

Venkatraman, N. and Ramanujam, V. (1986) Measurement of Business Performance in Strategy Research: A Comparison of Approaches. Academy of Management Review, 11, 801-814.

Wurjaningrum, Febriana. 2012. Pengaruh Perbaikan Kualitas Terhadap Kinerja Operasi Ukm Garmen Surabaya Dengan Perbaikan Produktivitas Sebagai Variabel Intervening. Buletin Studi Ekonomi. Vol. 17. No. 2. pp. 116-132.

Y. H. Chang, and C . H. Yeh. 2002. A survey analysis of service quality for domestic airlines', European Journal of Operational Research, Vol. 139, no. 1, pp. 166-177. 